\title{
P01.51. Light-emitting diode therapy reduces mechanical hypersensitivity induced by plantar incision model in mice via opioid mechanism
}

\author{
F Cidral-Filho*, L Mazzardo-Martins, D Martins, A OO Moré, A Soares dos Santos \\ From International Research Congress on Integrative Medicine and Health 2012 \\ Portland, Oregon, USA. 15-18 May 2012
}

\section{Purpose}

Evaluate the antihypersensitivity effect of Light Emitting Diode Therapy (LEDT) in the plantar incision (PI) model in mice as well as investigate the possible involvement of the opioid system in this effect.

\section{Methods}

The experiments were approved by the institution ethics committee under protocol n. 23080.006492/2011-61. Male Swiss mice were randomly divided in the following groups $(n=8)$ : naive, control (not treated), Off (LED device turned off), LEDT 1, 3, 5, 7 and 9 (treated with energy densities of 1 through $9 \mathrm{~J} / \mathrm{cm} 2$ ). Control, Off and LEDT groups were submitted to a $5 \mathrm{~mm}$ longitudinal PI (right hindpaw) under anesthesia (1-2\% isoflurane). Mechanical hypersensitivity $(\mathrm{MH})$ was assessed as withdrawal frequency percentage to 10 presentations of a $0.4 \mathrm{~g}$ von Frey filament. Evaluations were conducted before and on day 1 through 5 after PI. LEDT (MOLIMEDpen ${ }^{\circledR}$ device; $950 \mathrm{~nm}$ wavelength, $80 \mathrm{~mW} / \mathrm{cm} 2$ irradiance; 1 to $9 \mathrm{~J} / \mathrm{cm} 2$ energy density) was applied directly to the skin of the incision site.

\section{Results}

Results demonstrate that LEDT reduced MH in a doseresponse manner with best results obtained with $9 \mathrm{~J} / \mathrm{cm} 2$ (inhibition of $55 \pm 10 \%$ and effect lasting for 1 hour). Treatment with $1 \mathrm{~J} / \mathrm{cm} 2$ and with LED device turned off did not reduce $\mathrm{MH}$. Furthermore, LEDT as well as morphine ( $5 \mu \mathrm{g} / \mathrm{site}$ i.pl.) effects were blocked by intraperitoneal (i.p.), intraplantar (i.pl.) or intrathecal pre-administration of naloxone ( $1 \mathrm{mg} / \mathrm{kg}$ i.p.; $5 \mu \mathrm{g} / \mathrm{site}$ i.pl. or $5 \mu \mathrm{g} / \mathrm{site}$ i.t.) 20 minutes prior to LEDT or morphine treatment.

Federal University of Santa Catarina, Florianópolis, Brazil

\section{Conclusion}

LEDT reduced hypersensitivity induced by PI in mice via peripheral as well as central opioid mechanisms.

Sources of research support: UFSC, Capes.

Published: 12 June 2012

doi:10.1186/1472-6882-12-S1-P51

Cite this article as: Cidral-Filho et al: P01.51. Light-emitting diode therapy reduces mechanical hypersensitivity induced by plantar incision model in mice via opioid mechanism. BMC Complementary and Alternative Medicine 2012 12(Suppl 1):P51.
Submit your next manuscript to BioMed Central and take full advantage of:

- Convenient online submission

- Thorough peer review

- No space constraints or color figure charges

- Immediate publication on acceptance

- Inclusion in PubMed, CAS, Scopus and Google Scholar

- Research which is freely available for redistribution

\section{Ciomed Central}

